\title{
Design and Application in China of Trading Mechanism for Venture Capital
}

\author{
Luhao Huang, Mengjun Ge* \\ Department of Finance, College of Economics, Jinan University, Guangzhou, China \\ Email: ${ }^{\star}$ gemengjunjun@outlook.com
}

How to cite this paper: Huang, L.H. and Ge, M.J. (2019) Design and Application in China of Trading Mechanism for Venture Capital. Modern Economy, 10, 2134-2144. https://doi.org/10.4236/me.2019.109134

Received: August 28, 2019

Accepted: September 21, 2019

Published: September 24, 2019

Copyright $\odot 2019$ by author(s) and Scientific Research Publishing Inc. This work is licensed under the Creative Commons Attribution International License (CC BY 4.0).

http://creativecommons.org/licenses/by/4.0/

\begin{abstract}
Due to the factors of asymmetric information and inconsistent interests, venture capitalists and venture entrepreneurs have the problem of principal-agent relationship. This paper mainly explores the design arrangements of four transaction structures, namely, phased financing, choice of financial instruments, corporate governance structure and gambling agreement, and their local practices in China. The analysis results show that due to the imperfectness of our legal system, the immaturity of the capital market environment and other objective conditions, some good system designs, such as convertible equity and gambling agreements, are facing many difficulties in their implementation. Therefore, even though China's current venture capital is developing rapidly, the interests of China's venture investors have not been properly protected and venture entrepreneurs have not received sufficient incentives and supervision. If the current situation is not changed, it will be unfavorable to the development of China's venture capital industry in the long term.
\end{abstract}

\section{Keywords}

Venture Capital, Trading System Design, Phased Financing, Convertible Preferred Stock, Gambling Agreement

\section{Introduction}

In recent years, China's venture capital has developed rapidly and has become the second largest venture capital center after the United States. The number of venture capital institutions such as venture capital funds, venture capital management institutions and the total amount of management capital are increasing. As of 2016, the number of venture capital institutions in China reached 2045, an increase of 270 or $15.2 \%$ over 2015 . The total amount of venture capital man- 
agement capital in China is 827,710 million yuan, an increase of 162.38 billion yuan or $24.4 \%$ over 2015 [1]. Venture capital is generally targeted at high-growth, high-risk, innovative and innovative start-up enterprises with potential for development. By providing equity capital to these enterprises, the transformation of scientific and technological achievements into real productive forces is accelerated. In recent years, China's venture capital is mainly concentrated in the network industry, software industry, IT service industry and other high-tech industries. From the perspective of investors, the timing of investment in these enterprises can be divided into five stages: seed stage, initial stage, growth stage, mature stage and reconstruction stage. Venture capital projects are generally concentrated in the first three stages of an enterprise's growth cycle, namely, seed stage, initial stage and growth stage. Venture capital has a long cycle, usually 3 to 7 years. In 2016, the average withdrawal time of Chinese VCs was 4.13 years, while that of American VCs was 8.3 years [2]. In addition to capital investment, investors also provide value-added services such as management and consultation to investors.

Due to asymmetric information and inconsistent interests, venture capitalists and venture entrepreneurs have principal-agent problems. The requirement of venture capital fund for venture enterprises is to provide real information in time so that existing investments can be reasonably supervised and further investments can be evaluated. However, venture entrepreneurs are not willing to share all information with venture capitalists in time. Asymmetric information brings three problems: team motivation, adverse selection and moral hazard. Although venture capitalists participate in the investment by means of equity, their main interest goal is to sell or list the invested projects and realize the realization of owner's equity, and they do not require to obtain the control right of the enterprise. However, venture entrepreneurs demand control and long-term development of enterprises. Then, how to reduce the efficiency loss of both venture capital parties caused by the principal-agent problem? According to the previous study, the solution to this problem is to solve it through transaction structure design such as betting agreement and participation in post-investment management. This article will further discuss the specific scheme of designing the transaction structure of both parties in venture capital and its practice in China.

According to the existing literature, there is a considerable gap in the application of the solutions to the principal-agent problem of venture capitalists and venture entrepreneurs in China. From the content point of view, previous studies have generally put forward a specific transaction mechanism as a solution, and have not systematically examined the relationship between the transaction mechanism and the legal environment in China's overall market. Methodologically speaking, the existing research focuses on the construction of mathematical models, and its research conclusion is not based on real cases, so it is impossible to construct a systematic theoretical system. Through literature review, this paper systematically sorts out the current relevant literature on the domestic ap- 
plication of venture capital trading mechanism in China, and answers the methods that venture enterprises can adopt to deal with the contradictions with venture capitalists, providing guidance for venture capital companies and venture enterprises to optimize contract design, equity structure and improve contract efficiency. Therefore, the main contribution and originality of this paper lie in enriching the theory of venture capital applied in China and filling in the gap in the current theory of venture capital in China.

The main research method of this paper is literature review method. Firstly, a large number of relevant documents related to the design of venture capital trading mechanism are consulted, and then they are classified and organized. The venture capital trading structures involved in all the documents are divided into four categories: staged financing, choice of financial instruments, corporate governance structure and gambling agreement. The documents selected in this paper take into account both the pioneering and practical nature of the theory, and examine in detail the current development and institutional environment of China's venture capital market, fully showing the four transaction structure design arrangements and their local practice in China.

The structure of this paper is as follows. The second part will introduce four commonly used transaction structure design mechanisms in venture capital, including phased financing in the investment phase, the use of convertible financial instruments in the equity structure of venture enterprises, the distribution of shareholders' power and board seats in the corporate governance structure of venture enterprises, and a gambling agreement to coordinate the interests between management and investors. The third part is a summary of the whole article. The main conclusion is that good transaction structure design and post-investment management can effectively motivate the management. However, due to the imperfect domestic legal environment and immature capital market in China, the application of these transaction structure designs in China is restricted.

\section{The Transaction Structure Design}

\subsection{Investment Mode Design: Financing in Stages}

Phased financing refers to that when venture capitalists invest in enterprise projects, they generally do not invest all the funds required by the enterprise or needed to complete its business plan at one time, but will adopt a gradual and multi-round investment process according to the actual situation of the enterprise. Venture capitalists will regularly evaluate factors such as the market prospect of the enterprise, the performance of the management and the realization of the stage objectives, and then decide whether to continue to invest, the amount of investment, the transaction price, the investment agreement, etc. [3]. Phased financing urges venture entrepreneurs to make venture capitalists follow up the project when obtaining each round of financing, so as to ensure the close connection between venture capitalists and venture enterprises, fully and accurately 
grasp the actual situation of enterprises, and effectively solve the problem of asymmetric information between the financing parties. Through this form, venture capitalists reserve the right to give up investment projects with poor prospects, and at the same time play an incentive and constraint role on the behavior of entrepreneurs. But this method also has its drawbacks. In the case of phased financing, enterprises always want to continue the project. Cornelli and Yosha (2003) studies show that entrepreneurs have incentives to manipulate short-term project signals in order to reduce the possibility of project liquidation before venture capitalists make decisions on the next financing or liquidation. Entrepreneurs' tendency to short-term goals will have a negative impact on the long-term prospects of the project [4]. Wan Liang and Zhou (2012) established a multi-stage dynamic game model for venture capitalists and venture entrepreneurs, analyzed and deduced the best strategy that venture capitalists and venture entrepreneurs should adopt in the multi-stage game, and proved that venture capitalists can solve the defect of stage financing by selecting appropriate equity-creditor financing tools [5].

In the past ten years, China's domestic venture capital institutions still dominate the financing of invested projects in the first round. Showing in Figure 1, from 2007 to 2016, the ratio of initial financing to subsequent financing for venture capital projects in China is about 7:3 each year. This shows that a large proportion of venture capital projects in China will not be further invested by venture investors.

\subsection{Conversion of Control Rights: Choice of Financial Instruments}

In the equity structure of start-up enterprises, the core team holds most of the equity. Enterprise management holds common shares, while venture capitalists usually hold preferred shares or convertible financial instruments. Generally, venture capitalists do not require holding shares, but the ultimate shareholding

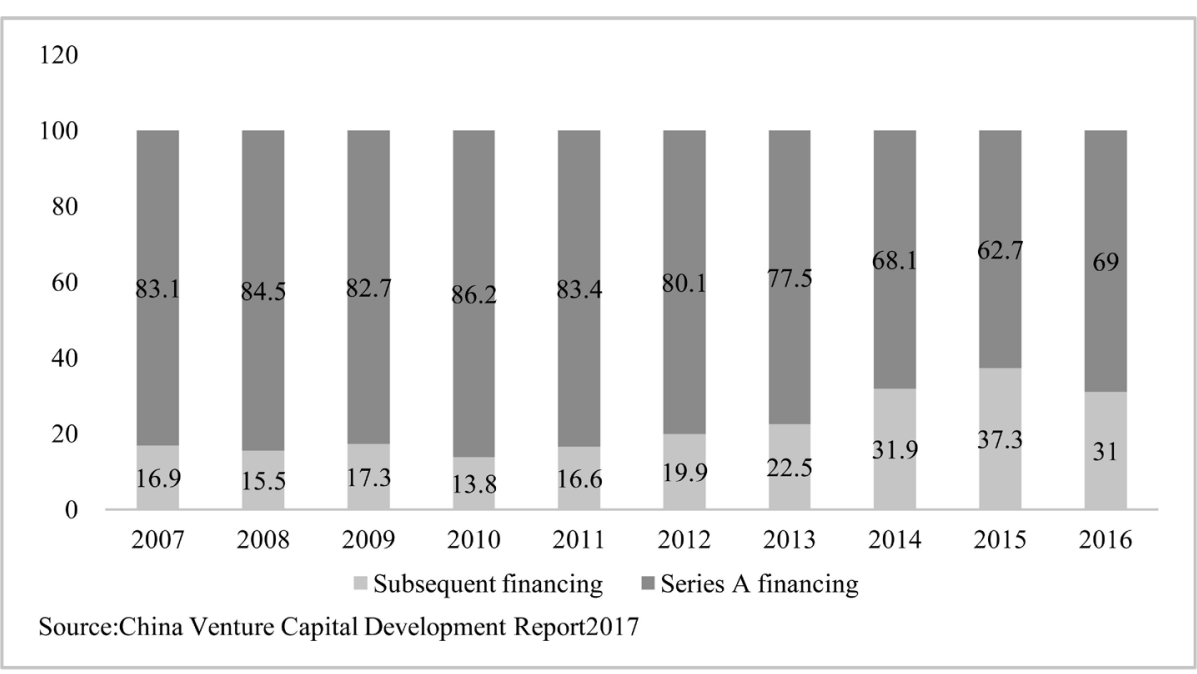

Figure 1. Ratio of first round financing and subsequent financing of venture capital in China from 2007 to 2016 . 
ratio of enterprise management depends on the quality of its operation. The conversion ratio of preferred shares is not fixed, but is adjusted according to the quality of enterprise operation. Scholars at home and abroad have studied the distribution of control rights between venture capitalists and venture entrepreneurs. Aghion and Bolton (1992) put forward "the theory of optimal order of governance structure": when a venture enterprise starts, it is optimal for the venture entrepreneur to have control. If this is not enough to protect the rights and interests of investors, camera control should be adopted, that is, venture entrepreneurs have control when the business is in good condition and investors have control when the business is in bad condition. If the rights and interests of investors are still not adequately protected, investors should have control. They believe that this distribution of control rights can reduce the conflicts of interest between venture entrepreneurs and investors, thus protecting the interests of investors [6]. Schmidt (2003) established a sequential double moral hazard model, proving that the use of convertible bonds can ensure that both parties effectively provide efforts [7].

In the income structure of the management of the enterprise that accepts venture capital, equity income is the most important. The higher the profit of the enterprise, the lower the proportion of preferred shares converted into common shares by venture capitalists. However, the price per share increases due to the increase in profit, which can maintain a higher stock market value and realize a win-win situation. However, if the enterprise is not managed properly, not only will the share conversion ratio increase, but also the value of common shares will be greatly reduced after the dividend of preferred shares. From a system point of view, convertible financial instruments are a special interest adjustment mechanism between venture capitalists and the management of venture enterprises, which plays many roles such as controlling risks, protecting investors and encouraging the management of enterprises [8].

The alternative conversion financial instruments mainly include convertible bonds, corporate bonds with share options, preferred shares and convertible preferred shares. Convertible bonds are short for convertible corporate bonds. It is a special corporate bond that can be converted into common stock at a specific time and under specific conditions. Convertible bonds are characterized by double options. On the one hand, investors can choose whether to convert shares or not and bear the opportunity cost of lower interest rate of convertible bonds. On the other hand, the issuer of convertible bonds has the option to implement the redemption clause and pay a higher interest rate than the convertible bonds without the redemption clause. Corporate bonds with share options refer to that while venture capital enters the invested enterprise in the form of creditor's rights capital, the invested enterprise simultaneously gives venture investors a long-term option, i.e. allows venture investors to buy a set number of stocks at a certain price in the future. Preferred stock is a kind of ownership securities, which has several priorities compared with common stock. For exam- 
ple, preferred stock shareholders get the dividend income of start-up enterprises before common stock shareholders. When a start-up enterprise goes bankrupt and liquidates, preferred shareholders will receive the remaining assets of the start-up enterprise before common shareholders. However, preferred shares do not have control, that is, they have no right to ask about the management decisions of start-up enterprises. Convertible preferred stock is an option that allows its holder to convert preferred stock into common stock under certain conditions on the basis of preferred stock in venture capital markets in developed countries. It has multiple attributes of bonds, common stock, preferred stock and option. It is a trading tool with balanced interests and compatible incentives. It has become the most commonly used investment tool for venture capitalists to invest in start-up enterprises.

Most companies listed in the United States use convertible preferred shares for financing, while most companies listed in Hong Kong use convertible bonds and common shares for financing, as for companies listed in the mainland, they basically use common shares for financing due to restrictions on the issuance of preferred shares and convertible bonds. Preferred stock, a common type of shares in western countries, has not been fully utilized in China, and the issuance of convertible corporate bonds and share option bonds is also subject to various restrictions. With regard to convertible preferred shares, China's current "Company Law" and "Securities Law" have not made corresponding legal provisions on the issue of convertible preferred shares (issue subject, issue conditions, issue scale and issue method, etc.). With regard to convertible bonds, although the relevant laws specify the operating procedures of convertible bonds and there are laws to be followed in implementing and promoting convertible bonds, strict restrictions have been imposed on the issuers of convertible bonds. Venture enterprises (mainly high-tech small enterprises) in the initial and growth stages are generally unable to meet the stringent conditions for issuing convertible bonds.

In addition to legal reasons, there are administrative reasons that hinder the widespread use of convertible preferred shares in China. Even if it is possible to use convertible bonds, the payment of interest is ignored only for future conversion. China is very sensitive to the change of ownership structure of unlisted companies and companies to be listed. The latest requirement of the CSRC is that there should be no major equity change within one year before the listing application is filed, and the responsible equity will be locked for three years after listing. However, the ownership change itself also requires a long approval period, which takes 4 - 6 months in the departments of industry and commerce, taxation, commerce, etc. Long waiting may miss a good market environment, so the price of time paid for the conversion of common shares cannot be accepted by venture investors [9].

\subsection{Corporate Governance Structure: Shareholder Power and Board Seats}

Venture capital, as a resource-embedded capital, can exercise shareholders' 
power through equity or directors' power through the board of directors [10].

The exercise of shareholder power through equity is related to the shareholding ratio of venture entrepreneurs. Bottazzi et al. (2008) research results show that the impact of venture capital institutions on invested enterprises is significantly positively related to their shareholding ratio. The higher the shareholding ratio, the stronger the ability to intervene and control the management activities of invested enterprises, and the higher the value of providing value-added services such as follow-up financing and professional management [11].

The supervision system for venture capitalists to start-up enterprises is realized through voting rights on the board of directors and the board of supervisors. The board of directors has the right to appoint and dismiss enterprise management personnel, and can guide and supervise the operation of the enterprise. Therefore, taking a seat on the board of directors is a means for venture investors to effectively supervise and restrain the management. Venture capitalists often occupy one or more seats on the board of directors of start-up enterprises. Venture investors often use convertible preferred shares and other financial instruments to inject capital into start-up enterprises, and often have the right to vote or even veto on major issues. One-vote veto power is also called veto power on important matters or protective rights, which refers to the veto power that venture investors have on the decision-making on important matters of start-up enterprises [12]. The reason why venture investors demand one-vote veto power is mainly due to the need to protect their interests as small shareholders and control the risks of the company. By exercising the right to make decisions in the opposite direction, venture investors can take some initiative in matters related to their own interests. Therefore, even if investors do not have a majority of seats on the board of directors, since venture investors have significant voting rights, funds can also form effective constraints on entrepreneurs and management.

Statistics show that in 2016, 66.97\% of venture capital investment projects in China have a shareholding of less than $10 \%$. However the proportion of projects with more than $50 \%$ shareholding is only $3.13 \%$. Showing in Table 1, venture capital institutions do not seek to hold shares, which is a holding weak position. Since 2008, China's venture capital institutions still focus on "general equity participation", with absolute and relative holding accounting for about $20 \%$.

Showing in Figure 2, "Board seats" and "providing management consultation" are the main supervision methods of venture capital institutions in China for invested projects.

How effective is China's venture capital participating in corporate governance? Jin and Wang (2010) studied the effect of venture capital intervention in the corporate governance of invested enterprises based on the sample of enterprises listed on Shenzhen SME board. The conclusion shows that the effect of venture capital intervention in the corporate governance of SMEs in China is not obvious. Apart from improving the market value, the impact on the governance 
Table 1. Equity structure of venture capital in china from 2008 to 2016 (Unit: \%).

\begin{tabular}{cccc}
\hline Year & Absolute control & Relative holding & General equity participation \\
\hline 2008 & 3.9 & 15.7 & 80 \\
2009 & 7.7 & 16.1 & 76.3 \\
2010 & 3.7 & 12.1 & 84.2 \\
2011 & 4.9 & 8.6 & 86.5 \\
2012 & 4.4 & 11 & 84.6 \\
2013 & 5.2 & 10.2 & 84.6 \\
2014 & 3.4 & 12.3 & 84.3 \\
2015 & 3.5 & 7.05 & 89.5 \\
2016 & 3.1 & 7.9 & 89 \\
\hline
\end{tabular}

\begin{tabular}{|c|c|}
\hline Board seat & 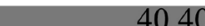 \\
\hline Provide management consulting & $33.90 \%$ \\
\hline Regulatory only & $16 \%$ \\
\hline else & $4.90 \%$ \\
\hline Financial Advisory & $4.80 \%$ \\
\hline
\end{tabular}

Figure 2. Supervision methods of shareholders participating in investment projects in 2016.

level and corporate performance is not significant. This shows that the venture capital industry in China still needs to be greatly improved [13]. And the effect of China's venture capital institutions participating in corporate governance is not remarkable. Obviously, the main reasons are as follows: there are too many speculative behaviors in China's securities market environment, while the long-term value investment behavior is less. Market value does not really reflect the level of corporate performance and governance in most cases. Therefore, venture capitalists will focus on strategies that can improve the market value of enterprises as soon as possible, instead of merely improving the level of corporate governance to realize the enhancement of market value. The imperfection of relevant financial instruments has deprived venture capital institutions of effective supervision tools. As well as the culture that small and medium-sized enterprises in China emphasize the personal will of the founders, hinder the effective supervision of venture capital institutions.

\subsection{Gambling Agreement}

Gambling agreement originated from Anglo-American legal system and has been widely used in the field of venture capital in our country. It is also called valuation adjustment agreement. It refers to a series of financial terms and arrangements made by investors and financiers to ensure their respective interests. 
Usually, the two parties take the performance index of the target company as the standard and make an agreement on the future uncertainty. If the agreed conditions appear, the investors shall exercise the valuation adjustment right to make up for the loss of overestimated enterprise value. On the other hand, the financier exercises a right to compensate for the loss of undervalued enterprises [14].

Specifically, the clauses in the gambling agreement can be broadly divided into anti-dilution clauses, control rights clauses and withdrawal clauses. In order to prevent the proportion of shares owned by the venture capitalist from decreasing when the enterprise issues new shares, it is generally required to ensure that the venture investor can obtain at least new shares corresponding to the proportion of its original shares, or to convert shares at the low price of later financing or at the weighted average price of shares during the subsequent financing of the enterprise. The control right clause is a clause set up to ensure the supervision and control of the management. Withdrawal clauses mainly include repurchase clauses and liquidation priority clauses. The repurchase clause stipulates that under certain conditions, the company needs to repurchase the shares of the investor, so that the venture investor can recover the investment under certain conditions without taking investment risks. The repurchase price can be based on the fair market price or the original purchase price plus unpaid interest. The liquidation priority clause stipulates that investors who hold preferred shares shall have the priority to allocate the rights to holders of common shares in the event of liquidation, dissolution or overall sale of the company. In this case, the risks of enterprise operation shall be borne to a large extent by the financier, while the investors have avoided the corresponding risks.

As a valuation adjustment mechanism, the gambling agreement coordinates the different interests of investors and management (or original major shareholders). First, financiers protect their own interests through the design of corresponding clauses, such as redemption clauses and restrictive clauses. Secondly, the enthusiasm of the management has been greatly improved by dynamically determining the ownership of the enterprise's income right or control right. The management must make every effort to reach the judgment standard, otherwise it will probably lose the control right or profit right of the enterprise. Finally, the common interests of both sides of this mechanism compromise the creation of enterprise value, which is conducive to the promotion of enterprise value [15].

As a relatively novel financial innovation, the gambling agreement has been widely used in the field of venture capital in China. However, compared with mature practices abroad, there are many problems and difficulties in the implementation of the gambling agreement, especially when the gambling fails. In practice, some enterprises have succeeded in gambling and achieved good benefits, while others have failed in gambling for various reasons and paid a heavy price.

At present, there is no explicit legal regulation on gambling agreements in our country. According to Article 124 of China's Contract Law, this agreement is an 
anonymous contract in the contract law. What kinds of legal adjustments should be applied to such nameless contracts and whether the agreement is effective are controversial issues in practice. Therefore, disputes arising from gambling agreements are constantly appearing in practice. Judging from the content of the gambling agreement, the gambling agreement belongs to the lucky contract. To investigate whether the gambling agreement is legal as a kind of lucky contract, we need to investigate from the following aspects: whether the contract subject is qualified, whether the party's intention is true, whether the contract content is legal, whether it violates the public order and good customs, and whether it damages the public interest. At present, the most controversial point in practice is whether the content of the gambling agreement meets the legal requirements and whether it embodies the principle of equal value and compensation. In the gambling agreement, the parties to the gambling have agreed on the conditions for investing or accepting equity through the gambling clause. No matter whether the financier meets the agreed performance standard, the investor will get the corresponding return. This is obviously different from the content of the company investor sharing profits and risks according to the proportion of investment stipulated in China's "Company Law". Therefore, some people question the legal effect of the gambling clause [16]. Although the gambling agreement is an effective mechanism to balance the interests of investors and financiers, the legal soil for its application in China is not mature enough and the local legal environment needs further optimization.

\section{Summary}

The principal-agent problem between venture capitalists and venture entrepreneurs has always been a hot topic in the field of venture capital research. Chinese and foreign scholars have determined a series of institutional arrangements, and these transaction design structures have also been widely used in practice. Good transaction structure design and post-investment management can effectively motivate the management and unify the interests of management and shareholders, thus ensuring the financial value-added objectives of venture capitalists. Establish and clarify the rules of procedure in advance between venture capitalists and team founders, and set up a supervision and restriction mechanism to prevent management from seeking maximum benefits at the expense of investors. In addition, it can also prevent market operation risks and legal risks, and transfer part of the market operation risks to the actual controllers of the enterprise to protect investors to a certain extent. Although there are many venture capital institutions in our country and the enthusiasm of venture investors and entrepreneurs is high, due to the imperfect domestic legal environment, immature capital market and other factors, which restrict the application of these transaction structure designs in our country, the interests of our country's venture investors have not been properly protected, and venture entrepreneurs have not received sufficient incentives and supervision. If the current situation is not 
changed, it will be unfavorable to the development of our country's venture capital industry in the long run.

\section{Conflicts of Interest}

The authors declare no conflicts of interest regarding the publication of this paper.

\section{References}

[1] China Institute of Science and Technology Development Strategy (2017) China Venture Capital Development Report 2017. Economic Management Press, Beijing, 1-2.

[2] China Institute of Science and Technology Development Strategy (2017) China Venture Capital Development Report 2017. Economic Management Press, Beijing, 31.

[3] China Venture Capital Research Institute (2017) Venture Capitalist. China Development Press, Beijing, 247-248.

[4] Cornelli, F. and Yosha, O. (2003) Stage Financing and the Role of Convertible Securities. The Review of Economic Studies, 70, 1-32. https://doi.org/10.1111/1467-937X.00235

[5] Wan, L.Y. and Zhou, H. (2012) Multi-Stage Game Analysis of Optimal Financing Contract in Venture Capital. Science and Technology Management Research, 32, 236-239.

[6] Yao, Z., Wang, X.Y. and Cheng, Y.J. (2011) Research on the Motivation and Mechanism of Setting Venture Capital Contract Terms. Management World, No. 2, 127-141.

[7] Schmidt, K.M. (2002) Convertible Securities and Venture Capital Finance. Mimeo, Stanford University and University of Munich.

[8] An, W. (2009) Research on Application of Convertible Financial Instruments in Venture Capital Industry. Shanghai Jiao Tong University, Shanghai.

[9] Gao, Yi. (2012) Research on Venture Capital and Convertible Securities. Contemporary Economy, No. 8, 122-123.

[10] Xu, H., Lin, Z.G. and Zhu, Y.P. (2017) Heterogeneity of Venture Capital, Corporate Governance Mechanism and Earnings Management before IPO. Financial Review, 228, 69-78.

[11] Bottazzi, L., Rin, M.D. and Hellmann, T. (2008) Who Are the Active Investors?: Evidence from Venture Capital. Journal of Financial Economics, 89, 488-512. https://doi.org/10.1016/j.jfineco.2007.09.003

[12] China Venture Capital Research Institute (2017) Venture Capitalist. China Development Press, Beijing, 254-255.

[13] Jin, M. and Wang, J. (2010) Research on the Mechanism and Effect of Venture Capital Involvement in Corporate Governance of Small and Medium-Sized Enterprises. Financial Issues, 154, 84-90.

[14] Hu, X.K. (2011) Research on the Enforceability of "Gambling Agreement" in Venture Capital Field. Securities Market Herald, No. 9, 68-73.

[15] China Venture Capital Research Institute (2017) Venture Capitalist. China Development Press, Beijing, 262-263.

[16] Xie, H.X. (2010) Analysis on Legal Nature of Gambling Agreement. Journal of Law, No. 1, 73-76. 